\title{
FUEL CELL FED INDUCTION MOTOR SPEED CONTROL THROUGH Z SOURCE INVERTER
}

\author{
Balabomma eswararao $^{1 *}$, B. Sankara prasad ${ }^{2}$, \\ ${ }^{1} \mathrm{M}$. Tech student, ${ }^{2} \mathrm{HOD}$ and Associate professor \\ ${ }^{* 1,2}$ Electrical And Electronic Department, St. Theressa Institute of Engineering and Technology \\ *1Email: beeswar4@gmail.com
}

*Corresponding Author: -

Email: beeswar4@gmail.com

\begin{abstract}
: -
this paper presents the Z- source inverter feeding to an Induction motor (IM). This Z-source inverter is also be used to boost up the available low voltage DC supply from the fuel cell. This paper has been proposed the speed control of fuel cell fed induction motor through z source inverter. The speed control of an induction motor is a highly efficient this can be used in numerous adjustable speed applications. To achieve transient performance, the peak DC link voltage is employed, which improves rejection of disturbance. SVPWM is used in switching algorithm. The closed loop SVPWM control technique of an induction motor is shown. This technique is widely used in industry. The performance of the proposed speed control method is verified through MATLAB/simulation. The simulation results of proposed scheme present good dynamic and steady state performance over the traditional voltage source inverter fed induction motor drive.
\end{abstract}

Key words: fuel cell, z-source inverter, induction motor, DTC-SVM, maximum boost converter

\section{(c) $(\$)$}




\section{INTRODUCTION}

The improved ZSI can be applied to areas where the input DC voltage is unreliable or it is of highly varying in nature, thus making it useful in non-conventional sources of energy such as in photovoltaic systems and fuel cell applications in which the DC voltage can be boosted to the required value. Since the day of the invention of IM, it has served in many applications like industrial as well in household applications. For the choice of speed control if a motor drive, V/F method has been very popular out of all the speed control mechanisms, since it offers a wide range of speed control and good running as good transient response. In order to surmount the problems associate with conventional VSI like low output voltage, voltage sags and shut down critical loads [1], [2]. Z-source inverter can be used as buck or boost converter, i.e. as a CSI (Current source inverter) and also VSI (voltage source inverter). It also eliminates the shoot through fault occurrence. There are four methods for controlling the DC-link voltage of the ZSI: direct DC-link control [5], capacitor voltage control [3], indirect DC-link voltage control [4] and unified control [6]. In this paper DC link control of implementing with SVPWM and is fed induction motor drive through z source converter in order to achieve low speed to rated speed and also to enhance the system performance.

Fuel cells are an environmentally friendly renewable energy source that can be used in a wide range of applications. There are numerous advantages with the use of fuel cells for power generation. The biggest advantage is the environmental impact. Pure hydrogen fuel cells produce no harmful emissions, and even fuel cells that require a reformer produce significantly less emissions than their internal combustion generator counterparts.

[Section II presents the advantages and applications of fuel cell in the field of power electronics and drives. The Z-source inverter fed induction motor and SVPWM techniques are explained in section III. The closed loop speed control of induction motor is presented in section IV. The theoretical and modulation concepts presented in the paper have been verified through detailed MATLAB/SIMULATION in section IV. Finally the derived conclusions are presented in section V

\section{Fuel Cell}

Fuel cells are an environmentally friendly renewable energy source that can be used in a wide range of applications and are ideal for distributed power applications. Fuel cells are electrochemical devices that convert chemical energy, typically from Hydrogen, directly into electrical energy. Similar to a battery, a fuel cell consists of two electrodes (anode and cathode) and an electrolyte. The fuel is supplied to the anode where it is oxidized and produces positive ions that flow through the electrolyte. The electrons are directed outside creating current through the external circuit and then back to the cathode. At the cathode, oxygen (air) is supplied and reduced, consuming the electrons from the external circuit, and the only resultant byproduct is $\mathrm{H} 2 \mathrm{O}$ (water). Basic schematic of a fuel cell shown below

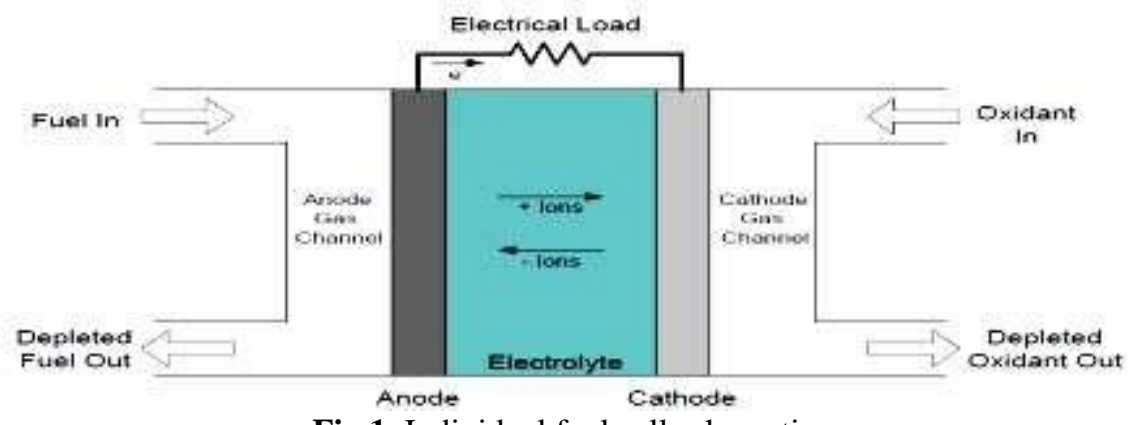

Fig.1. Individual fuel cell schematic

There are several different types of fuel cells, most often categorized by the type of electrolyte present. Four of the more common fuel cells are proton exchange membrane fuel cells (PEMFC), phosphoric acid fuel cells (PAFC), molten carbonate fuel cells (MCFC), and solid oxide fuel cells (SOFC)

The characteristics of these four are summarized in the below Table:

\begin{tabular}{|c|c|c|c|c|}
\hline & PEMFC & PAFC & MCFC & SOFC \\
\hline Electrolyte & $\begin{array}{l}\text { Polymer } \\
\text { Membrane }\end{array}$ & Phosphoric Acid & Molten Mixture & Ceramic \\
\hline $\begin{array}{l}\text { Operating } \\
\text { Temperature }\end{array}$ & $\leq 80^{\circ} \mathrm{C}$ & $205^{\circ} \mathrm{C}$ & $650^{\circ} \mathrm{C}$ & $800-1000^{\circ} \mathrm{C}$ \\
\hline Power Density & $>0.6 \mathrm{~W} / \mathrm{cm}^{2}$ & $0.2-0.3 \mathrm{~W} / \mathrm{cm}^{2}$ & $0.1-0.2 \mathrm{~W} / \mathrm{cm}^{2}$ & $0.25-0.35 \mathrm{~W} / \mathrm{cm}^{2}$ \\
\hline Charge Carrier & $\mathrm{H}^{+}$ & $\mathrm{H}^{+}$ & $\mathrm{CO}_{3}^{\circ}$ & $\mathrm{O}^{-}$ \\
\hline Catalyst & Platinum & Platinum & Nickel & Perovskites \\
\hline
\end{tabular}

The PEMFC is probably the most well-known fuel cell and shows promise for applications in the medium power range. Because of its efficiency and relatively low operating temperature range, the PEMFC is ideal for residential applications and is the chosen fuel cell for the system under study.

\section{A. V-I characteristic}

The V-I curve shows three main regions, but the ohmic region is the normal operating area of the fuel cell. Since the 
individual cell voltage in this region is only about $0.7 \mathrm{~V}$, they are often "stacked" together in series to produce a more useful voltage level. However, a large number of series cells can lead to reduced reliability since if one fails, the entire stacks stops functioning.

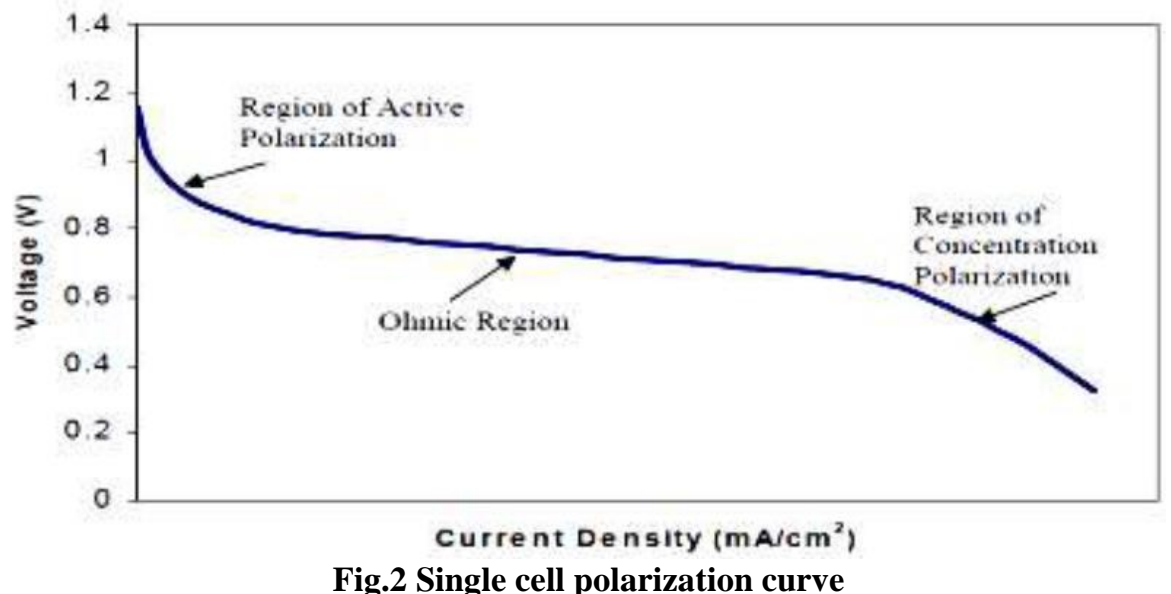

\section{B. Advantages:}

There are numerous advantages with the use of fuel cells for power generation. The biggest advantage, perhaps, is the environmental impact. Pure hydrogen fuel cells produce no harmful emissions, and even fuel cells that require a reformer produce significantly less emissions than their internal combustion generator counterparts. The efficiency of a fuel cell is another advantage over internal combustion engines, which are limited by the Carnot cycle efficiency. Due to the direct conversion from chemical to electrical energy, the efficiency of a fuel cell is in the 40-50\% range. Most of that power lost is in the form of heat, which can be captured relatively easily and put to use. Cogeneration is a big advantage with PEMFCs and the residential market. The heat produced from the fuel cell stack can be used to partially heat the home and the water. Lastly, fuel cell systems are very quiet and can fit nicely in a basement or a garage.

\section{Block Diagram For Fuel cell Fed Induction Motor Drive through Z-Source Inverter}

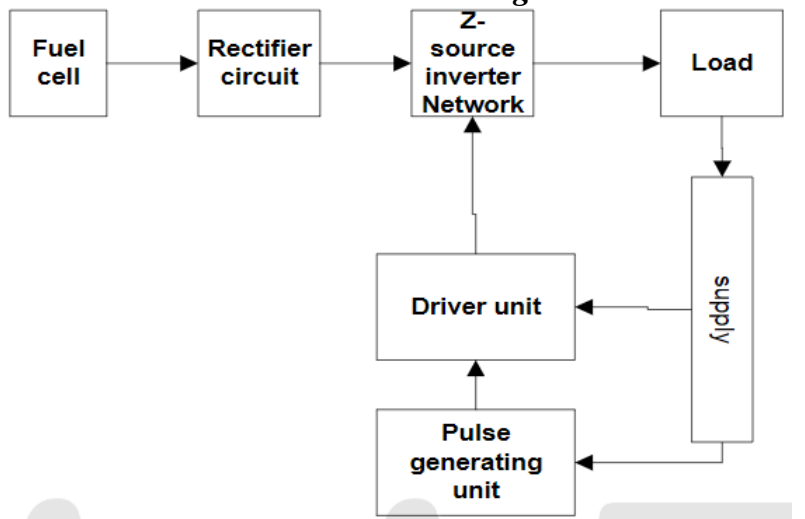

Fig. 3 Block diagram of proposed system

\section{III.Z SOURCE INVERTER FED INDUCTION MOTOR DRIVE}

\section{A. Z Source Inverter}

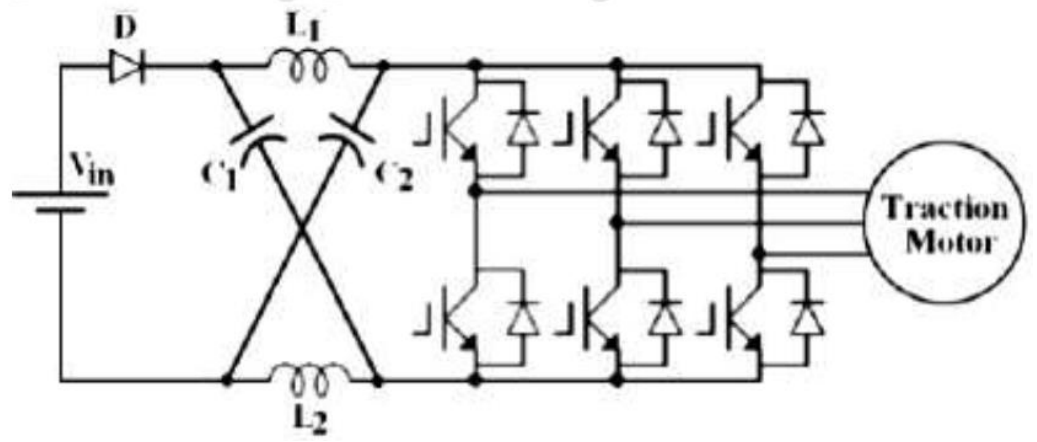

Figure. $4 \mathrm{Z}$ source inverter

Fig. 4 show the topologies of voltage type three phase Z- source inverter, where a DC voltage source and a conventional VSI with three phase legs are connected at opposite ends of the Z-source impedance network. A voltage type Z-source inverter can assume all active and null switching states of VSI. Unlike conventional VSI, a Z-source inverter has a unique feature of allowing both power switches of a phase leg to be turned ON simultaneously (shoot-through state) without 
damaging the inverter [1], [2]. The impact of the phase leg shoot- through with the inverter performance can be analyzed by considering the equivalent circuits shown in Fig.5. When in a shoot-through state during time interval T0, the inverter side of the Z-source network is shorted as in Fig. 5(a). Therefore (assuming $\mathrm{L} 1=\mathrm{L} 2=\mathrm{L}$ and $\mathrm{C} 1=\mathrm{C} 2=\mathrm{C}$ ):

$$
\begin{gathered}
v_{L 1}=v_{L 2}=v_{L}=V_{c 1}=V_{c 2}=V_{c} \\
v_{d}=v_{L}+V_{c}=2 V_{c} \\
v_{t}=0
\end{gathered}
$$

Alternatively, when in a non-shoot-through active or null state during time interval T1, current flows from the Zsource network through the inverter topology to the connected ac load. The inverter side of the Z-source network can now be represented by an equivalent current source, as shown in Fig. 5(b).

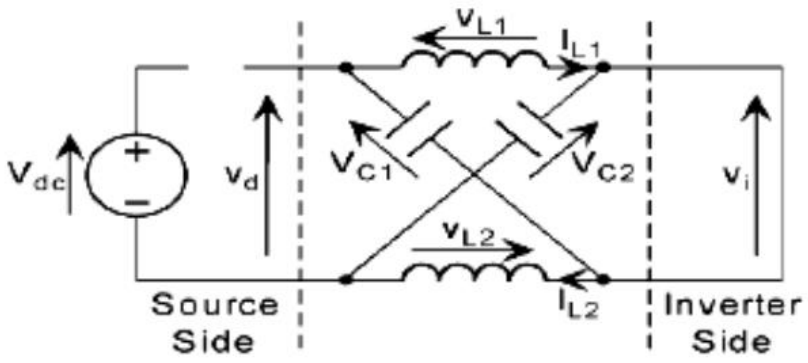

(a)

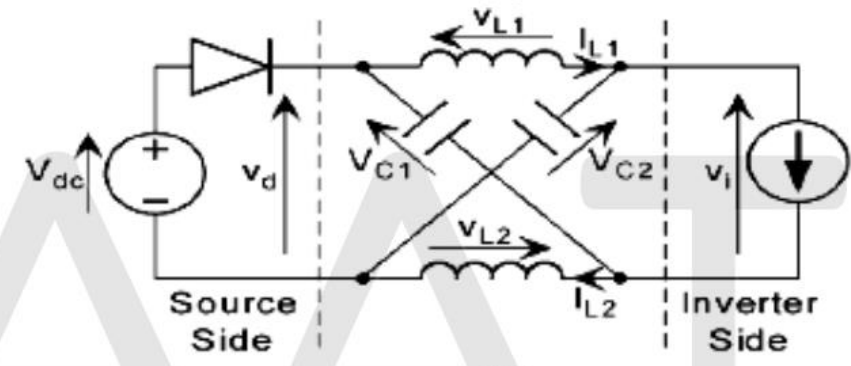

(b)

Fig 5. Equivalent circuit of $Z$ source inverter in (a). shoot through state and (b) non shoot through the state.

This current source sinks a finite current when in a non- hoot through active state and sinks zero current when in a non shoot- through null state. From Fig. 5 (b), the following equations can be written:

$$
\begin{aligned}
& v_{L}=V_{d c}-V_{c} \\
& v_{d}=V_{d c} \\
& v_{i}=V_{c}-v_{L}=2 v_{d}-V_{d c}
\end{aligned}
$$

Averaging the voltage VL across a Z-source inductor over a switching period ( 0 to $\mathrm{T}=\mathrm{T} 0+\mathrm{T} 1)$ then gives:

$$
v_{c}=\frac{T_{1}}{T_{1}-T_{0}} V_{d c}
$$

Using (2) and (3), the peak dc voltage $\mathrm{Vi}$ across the inverter phase-legs and the peak ac output voltage vx can be written as:

$$
\begin{gathered}
v_{i}=2 V_{c}-V_{d c}=\frac{1}{1-\frac{2 T_{0}}{T}} V_{d c}=B V_{d c} \\
v_{x}=M \frac{v_{i}}{2}=B\left\{M \frac{v_{d c}}{2}\right\}
\end{gathered}
$$

Where, $\mathrm{B}$ is the boost factor introduced by the shoot-through state, $\mathrm{M}$ is the modulation ratio commonly used for conventional VSI modulation and the term within gives the AC output of a conventional VSI. Obviously, equation (5) shows that the AC output voltage of a Z-source inverter is boosted by a factor of B (always $\geq 1$ ), which cannot be Achieved with a conventional VSI. 


\section{B. Space vector pulse width modulation: (SVPWM):}

This paper presents the space vector pulse width modulated (SVPWM) inverter fed drive. The objective to analyze the Induction motor through SVPWM fed inverter and also to analyze the harmonic in voltages \& current. There has been a number of Pulse width modulation (PWM) schemes in order to control the IM among those techniques most frequently used PWM schemes are sinusoidal pulse width modulation (SPWM) and space vector pulse width modulation (SVPWM). In this paper SVPWM is explained due to its advantage of reducing the harmonic content in voltage, thereby noticed that enhancement of output voltage by $15 \%$ \& gives smooth operating control over the proposed drive.
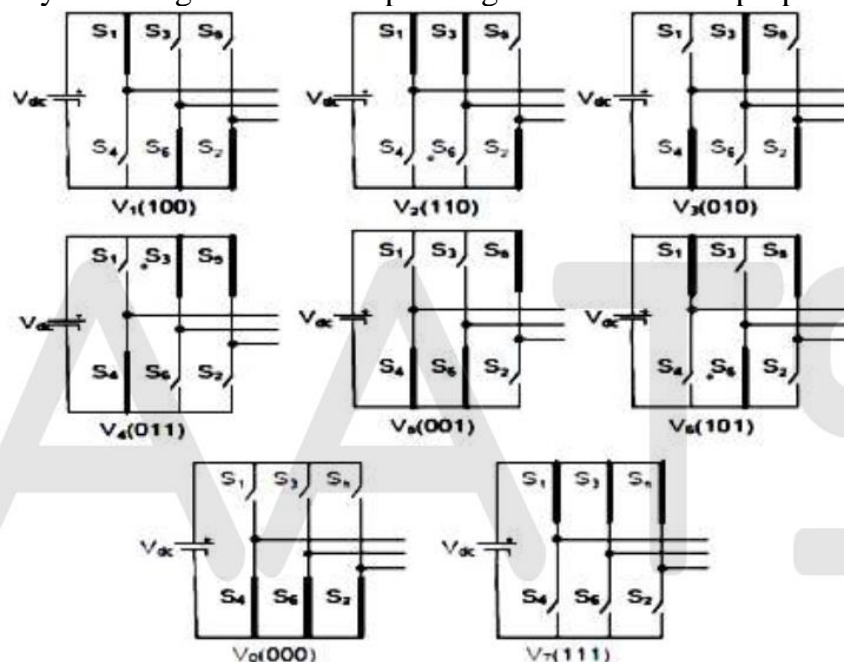

Fig.6. Different switching states of SVPWM

TABLE -1 SUMMERY OF SWITCHING STATES

\begin{tabular}{|c|c|c|c|c|c|}
\hline State & $\begin{array}{c}\text { ON } \\
\text { devices }\end{array}$ & Van & Vbn & Vcn & $\begin{array}{c}\text { Space voltage } \\
\text { vector }\end{array}$ \\
\hline 0 & S4 S6 S2 & 0 & 0 & 0 & $V 0=(000)$ \\
\hline 1 & S1 S6 S2 & $(2 / 3) \mathrm{Vdc}$ & $-(1 / 3) \mathrm{Vdc}$ & $-(1 / 3) \mathrm{Vdc}$ & $V 1=(100)$ \\
\hline 2 & S1 S3 S2 & $(1 / 3) \mathrm{Vdc}$ & $(1 / 3) \mathrm{Vdc}$ & $-(2 / 3) \mathrm{Vdc}$ & $V 2=(110)$ \\
\hline 3 & S4 S3 S2 & $-(1 / 3) \mathrm{Vdc}$ & $(2 / 3) \mathrm{Vdc}$ & $-(1 / 3) \mathrm{Vdc}$ & $V 3=(010)$ \\
\hline 4 & S4 S3 S5 & $-(2 / 3) \mathrm{Vdc}$ & $(1 / 3) \mathrm{Vdc}$ & $(1 / 3) \mathrm{Vdc}$ & $V 4=(011)$ \\
\hline 5 & S4 S6 S5 & $-(1 / 3) \mathrm{Vdc}$ & $-(1 / 3) \mathrm{Vdc}$ & $(2 / 3) \mathrm{Vdc}$ & $V 5=(001)$ \\
\hline 6 & S1 S6 S5 & $(1 / 3) \mathrm{Vdc}$ & $-(2 / 3) \mathrm{Vdc}$ & $(1 / 3) \mathrm{Vdc}$ & $V 6=(101)$ \\
\hline 7 & S1 S3 S5 & 0 & 0 & 0 & $V 7=(111)$ \\
\hline
\end{tabular}

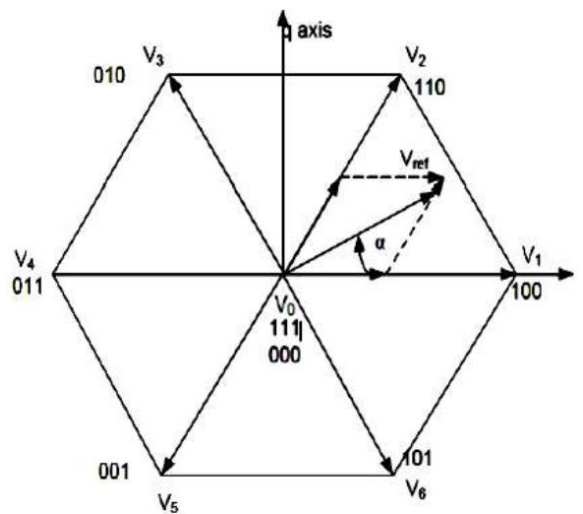

Fig.7 overview of Space vector modulation

\section{Peak DC Link Voltage Control}

In order to obtain good performance, the feedback control for DC link voltage of $\mathrm{z}$ source inverter is used [9].This will help in achieving good reference tracking and disturbance rejection and can improve dynamic response. The capacitor voltage $\mathrm{Vc}$ is equivalent to the $\mathrm{DC}$ link voltage of inverter, and can be boosted by controlling the shoot-through time duty ratio. The ZSI utilizes the shoot-through state to step up the DC link voltage by conducting both upper and lower switches of any phase legs. Thus, the ZSI can boost the voltage to desired AC output voltage, which is greater than the available DC link voltage. The relationship between the capacitor voltage and the DC link voltage bears a nonlinear relationship, which can affect the transient response of the system. In order to overcome the problem, an algorithm is proposed to control the capacitor voltage linearly [10]. The block diagram for the control can be represented as follows. 


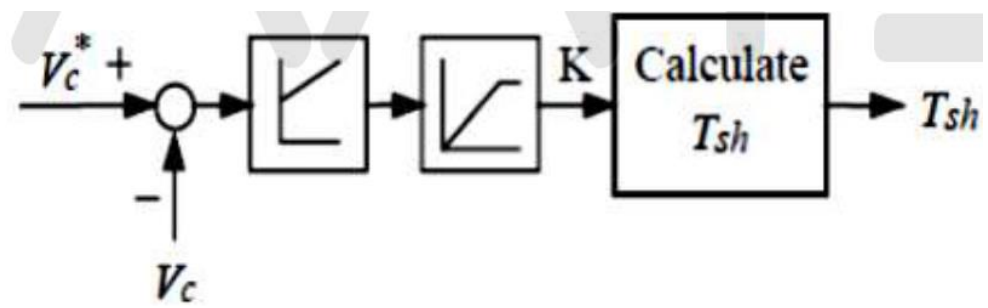

Fig. 8. Linearization of capacitor voltage

The $\mathrm{K}$ factor can be defined as

$$
k=\frac{V_{c}}{V_{d c}}
$$

Thus, the shoot through time can be calculated by the equation

$$
T_{s h}=\frac{K-1}{2 K-1} T_{S}
$$

The output of the PI controller equals K, from which it is possible to find out the shoot through duty ratio. As the K is proportional to the capacitor voltage, better transient performance of capacitor voltage can be obtained. The shoot through signals can be obtained can be OR ed with the PWM signal to obtain the desired response.

\section{IV.CLOSED LOOP SPEED CONTROL OF AN INDUCTION MOTOR}

Direct Torque Control with Space Vector Modulation (DTC-SVM) technique

The conventional DTC scheme has many drawbacks, such as: variable switching frequency, high current and torque ripples, starting and low-speed operation problems, in addition to high sampling frequency needed for digital implementation of the hysteresis controllers. To overcome these drawbacks, the space vector modulation is combined with the conventional DTC scheme for induction motor drive to provide a constant inverter switching frequency. In the DTC-SVM scheme, as shown in Figure 9, the torque and flux hysteresis comparators are replaced by PI controllers to regulate the flux and torque magnitudes respectively. The motor stator flux and the motor developed torque can be estimated by:

$$
\begin{gathered}
\Psi_{d s}=\int\left(v_{d s}-R_{s} i_{d s}\right) d t \\
\Psi_{q s}=\int\left(v_{q s}-R_{s} i_{q s}\right) d t \\
\left|\Psi_{d s}\right|=\sqrt{\Psi_{d s}^{2}+\Psi_{d s}^{2}} \\
\theta_{\Psi s}=\tan ^{-1} \frac{\Psi_{q s}}{\Psi_{d s}} \\
T_{e}=\frac{3}{2} P\left(\Psi_{d s} i_{q s}-\Psi_{q s} i_{d s}\right)
\end{gathered}
$$

The output of theses PI controllers generates the $\mathrm{d}$ and q components of the reference voltage command (vds* and vqs*) in the stator flux-oriented coordinates. After coordinate transformation, using the stator flux angle $\theta \psi s$, we get the reference voltage vectors vas* and $\mathrm{vs}^{*}$ ) in the stationary frame. These two components, which can control the stator flux and torque separately, are delivered to space vector modulator (SVM). The space vector modulator generates the inverter control signals, which ensures fixed inverter switching frequency. So the inverter switching frequency is significantly increased, and the associated torque ripple and current harmonics can be dramatically reduced, in comparison with the conventional switching table based DTC scheme. 


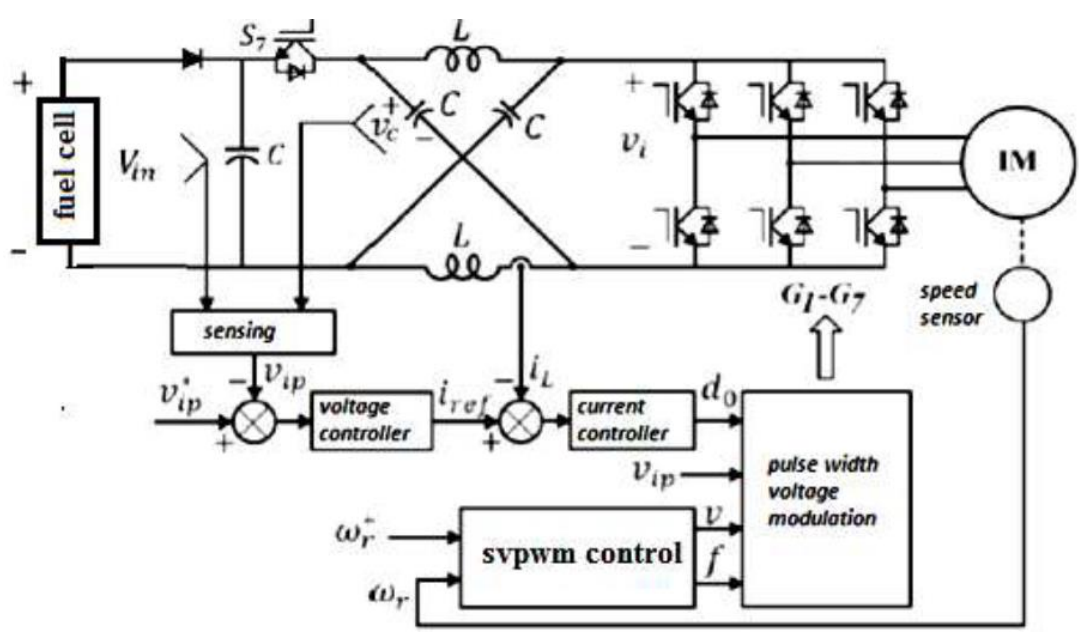

Figure 9. Closed loop speed control of three phase induction motor fed by a high performance ZSI

A dual loop controller is designed to control the average value of the DC link voltage by controlling the magnitude of its peak voltage based on a small signal model of the high performance ZSI. Figure 11, shows the calculated overall system efficiency at different load torque.

\section{RESULTS AND DISCUSSION}

Figure.10 shows DC- link voltage, source voltage, and inverter voltage. Fig.11. Load current and load voltages. Fig 12. Figure.13 rotor speed (RPM). Figure.14 electromagnetic torque.

\section{VI.SIMULATION RESULTS:}

\section{(a) DC-Voltage}

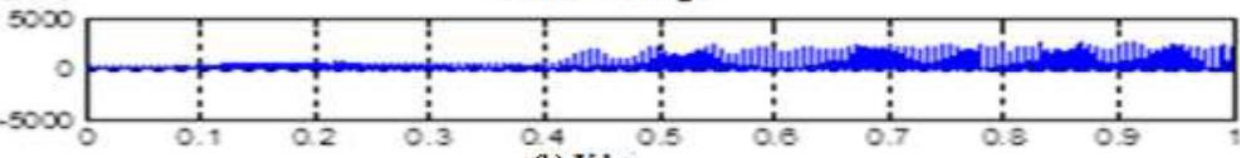

(b) Vde

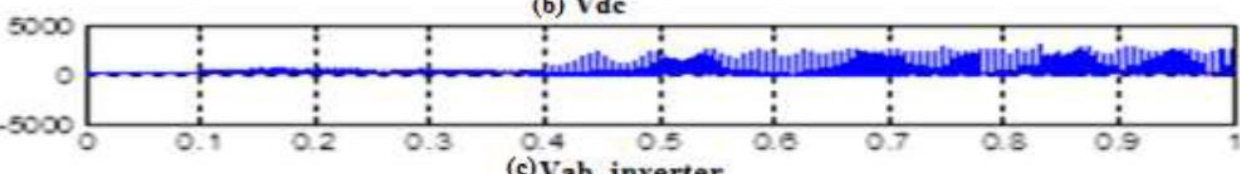

(c) Vab_inverter

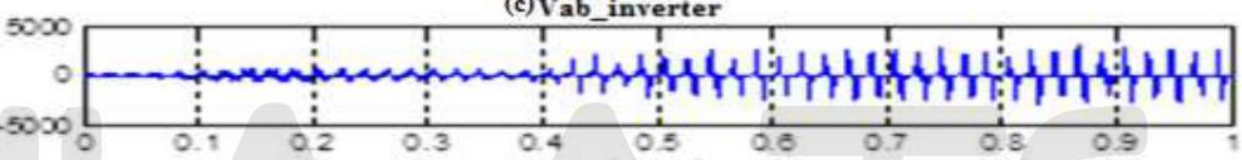

Fig.10. (a) DC-link voltage, (b) source voltage, and (c) inverter voltage

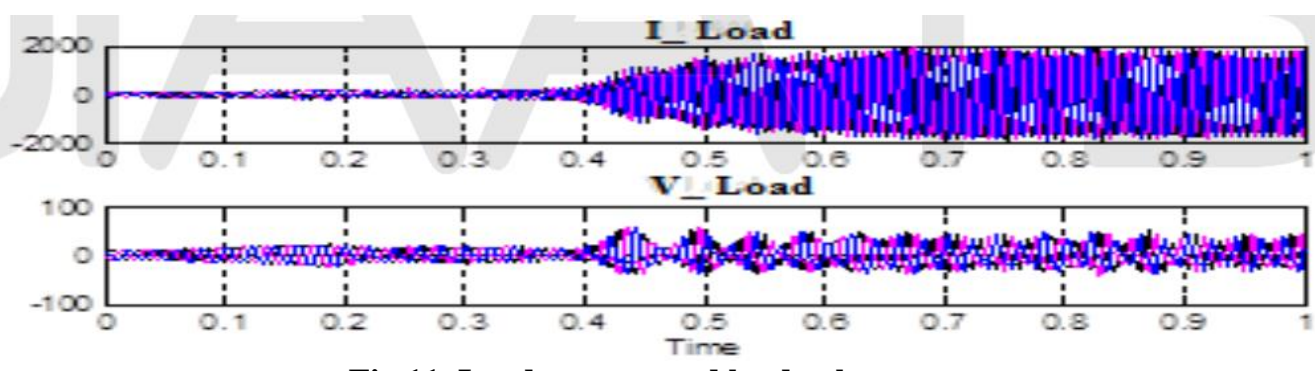

Fig.11. Load current and load voltages
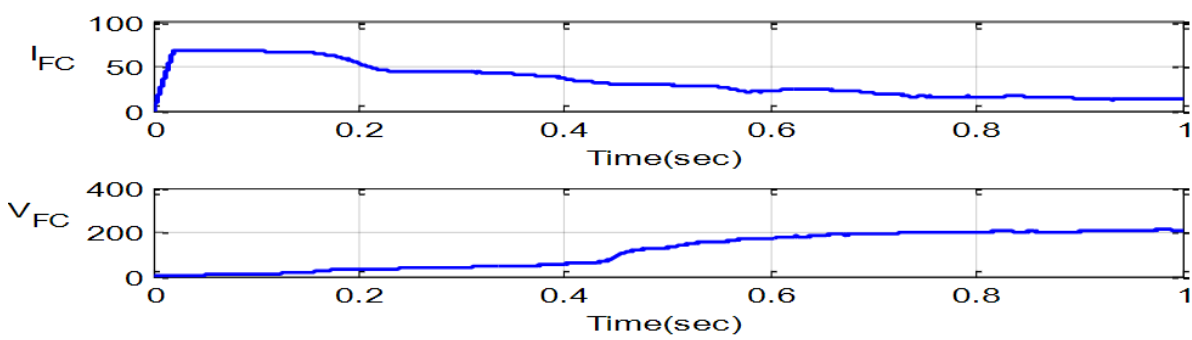

Fig 12 

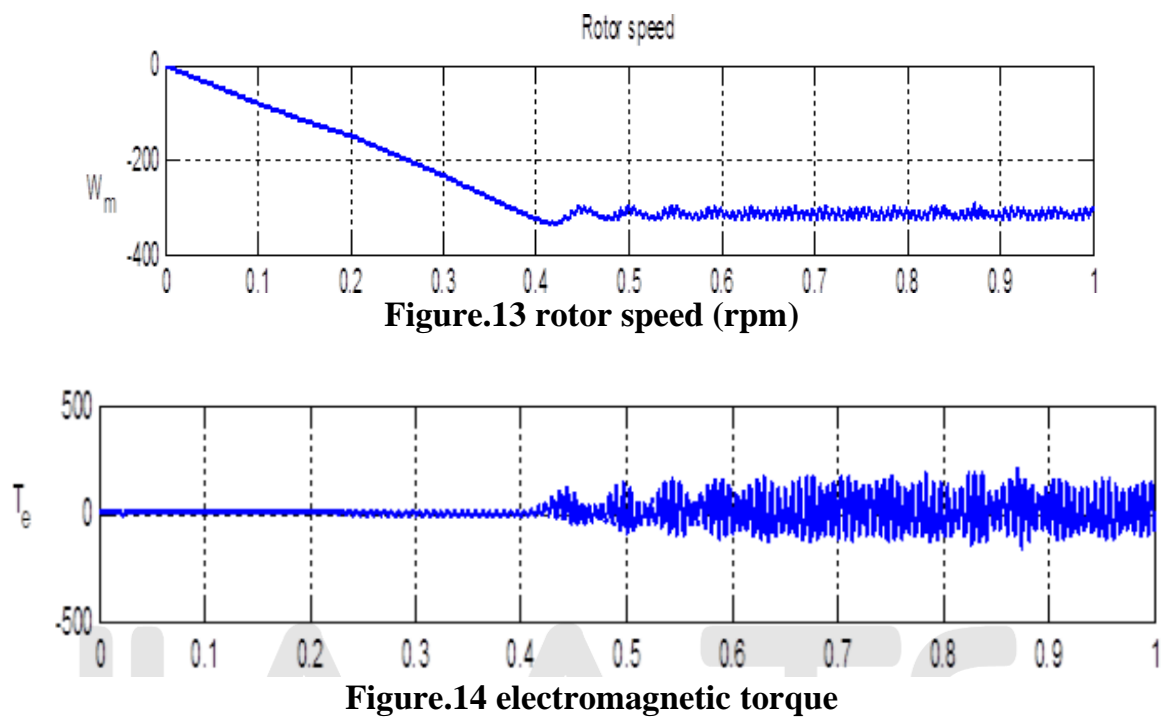

\section{Conclusion:}

The Z- source inverter is presented to feed an Induction motor (IM). This ZSI has also been used as a boosting device. Speed control of fuel cell fed induction motor through $\mathrm{z}$ source inverter is implemented and shows that the speed control of an induction motor is a highly efficient. Transient performance is achieved by employing the peak DC link voltage. SVPWM is used in switching algorithm. The closed loop SVPWM control technique of an induction motor is explained. The performance of the proposed speed control method is verified through MATLAB/simulation. The simulation results of source voltage, load voltage, DC link voltage and electromagnetic torque are shown in a simulation environment.

\section{References:}

[1].Peng, FZ. (2003). Z-source Inverter. IEEE Transactions on Industry Applications, 39(2), 504-510.

[2].F.Z.Peng, X.Yuan, X.Fang, and Z.Qian,"Z-Source Inverter for Adjustable Speed Drives", IEEE Power Electronics Letters, June, 2003

[3].Peng, F. Z., Shen, M., \& Joseph, A. (2005). Z-Source Inverters, Controls, and Motor Drive Applications. KIEE International Transactions on Electrical Machinery and Energy Conversion Systems., 5, 6-12.

[4].X. Ding, Z. Qian, S. Yang, B. Cui, and F. Peng, "A PID control strategy for dc-link boost voltage in Z-source inverter," in Proc. IEEE 22nd Annu. Appl. Power Electron. Conf., 2007, pp. 1145-1148.

[5].Liu, J., Hu, J., \& Xu, L. (2007). Dynamic Modeling and Analysis of Z-Source Converter- Derivation of AC Small Signal Model and Design-Oriented Analysis. IEEE Transactions of Power Electronics., 22(5), 1786-1796.

[6].X. Ding, Z. Qian, S. Yang, B. Cui, and F. Peng, "A direct peak DC-link boost voltage control strategy in Z-source inverter," in Proc. IEEE 22nd Annu. Appl. Power Electron. Conf., 2007, pp. 648-653.

[7].S. Yang, X. Ding, F. Zhang, F. Z. Peng, and Z. Qian, "Unified control technique for Z-source inverter," in Proc. IEEE Power Electron. Spec. Conf., 2008, pp. 3236-3242.

[8].Tsuji, M. ; Shuo Chen ; Hamasaki; Xiaodan Zhao ;Yamada, E. "A novel V/f control of induction motor for wide and precise speed operation", International Symposium on Power Electronics, Electrical Drives, Automation and Motion, June 2008

[9].Xinping Ding; Zhaoming Qian; Shuitao Yang; Bin Cui; Fangzheng Peng, "A New Adjustable-Speed Drives (ASD) System Based on High- Performance Z-Source Inverter" .42nd IAS Annual Meeting. Conference, Sept. 2007.

[10]. Ellabban, O., Van Mierlo, J., \& Lataire, P. (2011). Experimental Study of the Shoot- Through Boost Control Methods for the Z-Source Inverter. EPE- European Power Electronics and Drives Journal., 21(2), 18-29.

[11]. Q. Tran, T. Chun, J. Ahn, and H. Lee, "Algorithms for controlling both the dc boost and ac output voltage of Zsource inverter," IEEE Trans. Ind. Electron., vol. 54, no.5, pp. 2745-2750, Oct. 2007

[12]. Omar Ellabban, Joeri Van Mierlo and Philippe Lataire," Comparison between Different PWM Control Methods for Different Z-Source Inverter Topologies", The 13th European Conference on Power Electronics and Applications, EPE '09. 8-10 Sept. 2009

[13]. Loh PC, Vilathgamuwa DM, Gajanayake CJ, Lim YR, Teo CW. (2007). Transient Modeling and Analysis of PulseWidth Modulated Z-source Inverter. IEEE Transactions on Power Electronics., 22(2), 498-507. 